\title{
Idiomaticity as a Language Learning Barrier: The EFL Context of Saudi Arabia
}

\author{
Abdalla Elkheir Elgobshawi ${ }^{1}$ \\ ${ }^{1}$ Department of English Language \& Literature, College of Science and Humanities, Prince Sattam bin \\ Abdulaziz University, Saudi Arabia \\ Correspondence: Abdalla Elkheir Elgobshawi, Department of English Language \& Literature, College of \\ Science and Humanities at Al-Aflaj, Prince Sattam bin Abdulaziz University, P.O. Box 710, Al-Aflaj 11912, \\ Saudi Arabia. E-mail: abd.mohammed@psau.edu.sa
}

\author{
Received: January 5, 2020 Accepted: February 8, 2020 Online Published: March 14, 2020 \\ doi:10.5539/ijel.v10n3p59 URL: https://doi.org/10.5539/ijel.v10n3p59
}

\begin{abstract}
The aim of this paper is to investigate the impact of Idiomaticity on language learning and the extent to which it can be a language learning barrier. It contrasts the perspective of language teachers and the attitude of language learners regarding how idioms can influence language learning. The theoretical framework provides a description of the general properties of English idiomatic expressions and shows the relevance of idiomaticity to linguistic theory.

The paper is based on an analytical analysis and follows a quantitative approach in which two questionnaires are used to collect the data. The two questionnaires are administered to two independent samples: 20 participants representing ELT teachers at the tertiary level and 80 subjects representing Saudi EFL college students.

The data are then analyzed using SPSS (Statistical Package for the Social Sciences).

The study reveals learners' reasonable consensus on the issues assessed. They generally acknowledge the significance of idioms for language learning but with a general dissatisfaction with their status in learning and teaching contexts. Both teachers and learners view idioms as odd pieces of language that lack a uniform character and do not receive due attention in language syllabi and curricula. Teachers give different ratings on the pedagogical value of idioms, but they generally show low interest in teaching them.
\end{abstract}

Keywords: idiom, idiomaticity, learning barrier

\section{Introduction}

The issue of idiomaticity has a relatively recent history. The literature to be presented in this section will serve as a frame of reference upon which the researcher will depend when interpreting the results of his research to indicate potential significance.

First, idioms have an anomalous nature that sets them apart from most other conventionalized language forms. The use of idiomatic expressions is a character of speech that is as novel as other characters of the individual or group. This character, which might also be termed idiomaticity, is identifiable in speech and writing. It goes beyond the limits of the terms of descriptive linguistics because one's (native speaker) idiomaticity is identified as "his selection of expressions and the knowledge he has over and above rules and words" (Warren, 2005, p. 24).

As we have seen, the term "idiomaticity" is based on idiomatic featured speech. Linguistic researchers of idioms and idiomaticity focus on many questions in an attempt to gain clear answers according to language theory seeking them a clear status in language theory. The first of these questions relates to the identification and categorization of idioms. The lack of uniform and clear-cut criteria for defining what an idiom is makes it difficult to decide what to include under this category. The term "idiom", in relevant research, is applied to a particular category (Nunberg et al., 1994, p. 491) covering a wide range of expressions (of opposing dimensions) varying from the prototypical opaque kind such as "kick the bucket" to conventional forms such as collocations, proverbs, sayings, and clichés.

Most definitions of idioms focus on the fixedness of structure and the non-compositionality of meaning. These 
definitions often center on their lexical, syntactic, and semantic irregularities. Fernando and Flavell (1981) identified two approaches to defining idiomaticity. The first approach describes idiomaticity as a design feature of language and sets forth some peculiarities, such as non-literalness, that distinguish expressions as idioms. The second approach is structurally orientated and tends to be used to define idiomaticity on the basis of structural properties.

These attempts to define and categorize idioms are greatly dependent on characterizing their semantic and syntactic properties in a way that makes them fit with linguistic logic (where different language guises are interpreted according to standardized criteria). However, idioms have their irregularities that are sequences (Nunberg et al., 1994) of independent rhetorical and discursive functions of the expressions. These irregularities give them an anomalous nature of lexical, syntactic, and semantic dimensions that often deviate from the norms of linguistic logic.

\subsection{The Statement of the Problem}

English is typically an idiomatic language, meaning that learners need to develop an adequate knowledge of its idioms and attempt to assume a native-like idiomaticity. Learners often find the second target more difficult to accomplish because idiomaticity goes beyond the knowledge of idioms. They (i.e., learners) could have difficulty recognizing the use of idioms in natural settings and in their appropriate linguistic and cultural contexts. Furthermore, the nature of idioms and the abnormalities of their lexical, syntactic, and semantic properties could be responsible for the problems these learners might encounter. They seem to defy regular rules of syntax and semantics, and they cannot always be analyzed like lexical and syntactic items.

The status of EFL in the context of the current study indicates learners' avoidance of idiomatic English for two main reasons. First, learners lack familiarity with idioms in academic contexts. Second, they lack exposure to the target language in real contexts. This avoidance behavior may foster a negative or, at least, unwelcoming attitude toward the occurrence of idioms in learning contexts and ultimately makes them a learning barrier.

This research is an attempt to investigate the extent to which idioms could be language learning barriers and to contrast the perspective of language teachers with the attitude of learners toward how idioms can influence language learning.

\subsection{Research Objectives}

The study has the following two vocal objectives:

i) To investigate the impact of idiomaticity on language learning by contrasting the perspective of language teachers against the attitude of language learners regarding how idioms can influence language learning.

ii) To provide an analytical description of the syntactic and semantic properties of English idiomatic expressions.

\subsection{Research Questions}

The study poses the following questions:

i) How does idiomaticity influence language learning?

ii) How do both EFL college students and teachers view the impact of idiomaticity on language learning?

\section{Literature Review}

Relevant research on idioms also tackles the question of the processing of idioms by nonnative speakers. According to Kaszubski (2001), "learners, especially less advanced ones, tend to rely excessively on flexible, high-frequency, 'core' vocabulary items in their foreign language use" (p. 312).

Among the characteristics of idioms, as well as other conventionalized language forms, is that they make language performance appear native-like. Thus, the ultimate goal of a language learner is to assume a native-like competence.

Some studies on EFL learners' attitudes toward learning English idioms, such as that of Ababneh (2016, pp. 179-180), reveal that learners have a positive attitude toward both learning and producing them. This positive attitude is interpreted as learners' awareness of the fact that knowledge and mastery of idioms is a mark of competence in the target language. Ababneh's (2016) findings are in line with those of Al-Houti and Aldaihani (2018, pp. 147-148), who conducted their study in a Kuwaiti context and concluded that Kuwaiti EFL college students had positive attitudes toward idiom learning, particularly with respect to their importance, the difficulties involved, and learning strategies. Their findings showed that students were aware of the importance of idioms and their link to factors such as culture and proficiency. 
Similar positive attitudes toward learning English idioms were reported by Najarzadegan and Ketabi (2014, p. 611). Their results indicated that Iranian EFL learners have an extremely positive attitude toward both learning and producing English idioms.

Research also indicates a correlation between learners' academic success and the attitudes they share toward learning idioms. For example, Pucelj (2018, pp. 26-31) found that students with higher grades exhibited a more positive attitude. Pucelj's results are similar to those of Rifai (2010), who noted that students who had above-average grades also had significantly more positive attitudes and were more motivated to learn new idiomatic expressions. Furthermore, learners with positive attitudes toward learning new idioms acknowledge how important this type of figurative expression is both in spoken and in written discourse.

Teachers' beliefs generally have specific origins and causes, and they are dependent on different variables. Gabillon's study found the following:

Beliefs about teaching are constructed at school as a student, as a language learner and later in his/her professional contexts. The L2 teacher's theoretical-pedagogical beliefs are constructed much later in life during his/her professional education via interactions with other student teachers and teacher educators. ( $\mathrm{p}$. 198)

As for the concern of the present study, examining teachers' perspectives on idioms could offer insights on the impact of idiomaticity for FL learners.

Ramonda (2016, p. 141) indicated that idioms and their pedagogical value to second language learners are perceived in very different ways by second language educators and that the stark contrast in views among these educators is due to their very different views on the usefulness of idioms for these learners. Meanwhile, Rizq's study on ESL teachers' perspective of teaching English idioms to L2 learners (2015, pp. 46-47) showed that idioms are an important aspect of language learning and that they are significant because they are frequently used, especially in verbal communication. Participants attribute the difficulty of idioms to the following factors: the gap between the surface meaning of the idioms and the actual meaning, the correct usage of idioms, the lack of cultural and historical knowledge of the target language, and finding the equivalent idiom in the native language.

\section{Methodology}

\subsection{Participants}

A selection was made from two target groups: EFL teachers and Saudi EFL students. The EFL students consisted of 80 Saudi female EFL undergraduate students at the College of Science and Humanities, Price Sattam bin Abdul-Aziz University, Kingdom of Saudi Arabia. All were senior students in their final academic year. The $20 \mathrm{EFL}$ teachers participated as raters. These teachers held advanced degrees in applied linguistics or other related fields and had adequate teaching experience.

\subsection{Instrumentation}

For the instrumentation, the researcher developed two questionnaires: one for ELT teachers and the other for Saudi EFL students. The student questionnaire consisted of 10 items to which participants responded via a 5-point Likert rating. The questionnaire assessed learners' familiarity with English idioms, their views on the significance of idioms, and their attitudes toward the behavior of idioms.

The other instrument, the ELT teacher questionnaire, was designed to rate idioms in terms of their learnability, teachability, and relevance to learning/teaching materials.

\subsubsection{Validity and Reliability of the Research Instrument}

\subsubsection{The Student Questionnaire}

The student questionnaire was piloted with a group of $10 \mathrm{EFL}$ undergraduate students at the College of Science and Humanities, Prince Sattam bin Abdul-Aziz University, Kingdom of Saudi Arabia to ensure the reliability and validity of the items before the actual implementation.

The reliability of the questionnaire was established thorough Cronbach's alpha (see Table 1), and $\alpha=0.802$ was obtained.

Table 1 . Reliability statistics

\begin{tabular}{ll}
\hline Cronbach's Alpha & No. of Items \\
\hline 0.802 & 10 \\
\hline
\end{tabular}


Table 2. Item-total statistics

\begin{tabular}{lllll}
\hline & Scale Mean if Item Deleted & Scale Variance if Item Deleted & Corrected Item-Total Correlation & Cronbach's Alpha if Item Deleted \\
\hline 1 & 31.9886 & 33.552 & .551 & .776 \\
2 & 31.6932 & 34.353 & .553 & .777 \\
3 & 31.7500 & 33.661 & .524 & .779 \\
4 & 31.8068 & 34.571 & .454 & .788 \\
5 & 32.0227 & 34.436 & .423 & .792 \\
6 & 31.8523 & 34.886 & .494 & .783 \\
7 & 31.7955 & 34.808 & .493 & .783 \\
8 & 32.0227 & 34.045 & .459 & .788 \\
9 & 31.3750 & 35.616 & .462 & .787 \\
10 & 31.3523 & 36.438 & .372 & .796 \\
\hline
\end{tabular}

From Table 2, it can be seen that all the values of corrected item-total correlation are $<0.3$, and upon considering the column of the correlation coefficient if an item is deleted, it is clear that deleting any of the questionnaire items would not increase the current 0.8 correlation coefficient.

A consideration of the reliability coefficients of the subjects of the pilot sample showed that more than $50 \%$ of the student questionnaire was of an adequate validity and reliability and that it would help in obtaining an acceptable statistical analysis.

\subsubsection{Teachers' Questionnaire}

To ensure the validity of the teachers' questionnaire, the researcher consulted five ELT expert referees. He distributed copies of the ELT teachers' questionnaire along with the student questionnaire to these experts to garner their judgment, opinions, and recommendations on these instruments with regard to their suitability, relevance, and clarity.

The experts referred to were all Ph.D. holders. In addition to their teaching experience in the field of ELT, they were engaged in the supervision of ELT research for Ph.D., M.A., and M.Ed. degrees.

The suggestions and opinions of the experts on the construction and content of both the test and the questionnaire were taken into great consideration and were incorporated in the final version.

\subsection{Procedure}

An attitude questionnaire was administered to a sample of 20 EFL teachers. Copies were sent via email. As for the student questionnaire, the researcher obtained permission from the administration of the respective faculty. Copies of the student questionnaire were distributed by hand to subjects Some inquiries from respondents about some of the questionnaire's contents were given due attention and clarification.

\section{Data Analysis}

\subsection{Data Analysis of the Student Questionnaire}

This section provides analysis of the data obtained from administering the student questionnaire and the ELT teachers' questionnaire. The data were processed by the computer using the Statistical Package for Social Studies (SPSS) program. Some descriptive statistics, such as mean, median, and standard deviation, were used to identify any significant differences of the independent variables in the study.

To determine the criterion adopted in the study, the cell length was determined in the Likert pentatonic scale by calculating the range between the scale grades $(5-1=4)$ and then dividing it by the largest value in the scale to obtain the length of the cell (i.e., $4 \div 5=0.80$ ), after which this value was added to the lowest value in the scale (the beginning of the scale, which is one true " 1 "). This was to determine the upper limit of this cell, and thus the length of the cells became as follows:

(Range $=5-1=4$ [Highest value - Lowest value])

$$
\text { (Length of the cell }=4 \div 5=0.80 \text { [range/number of steps]) }
$$

The number 1.80 was added to the lowest value on the scale and was the integer number (1) used to set the maximum. 
Table 3. The criterion of study

\begin{tabular}{ll}
\hline Level of agreement & Cell length \\
\hline Very low & $1.00-1.80$ \\
Low & $1.81-2.60$ \\
Average & $2.61-3.40$ \\
High & $3.41-4.20$ \\
Very high & $4.21-5$ \\
\hline
\end{tabular}

The first part of the questionnaire covers the dimension that assesses learners' attitudes toward difficulties arising from the nature of English idioms (see Table 4). The researcher assumes that these difficulties are due to the linguistic complexities of idioms, which lack equivalents in the Ll. Moreover, processing idioms from L2 or FL requires a knowledge of their cultural background.

Table 4. First dimension (difficulties attributed to the nature of idioms)

\begin{tabular}{ll}
\hline 1 & I think idioms are difficult, and their lexical and syntactic rules are complex. \\
2 & I avoid the use of idioms because they themselves need to be explained. I prefer to use plain vocabulary. \\
3 & I find idioms hard to learn especially when they do not have equivalents in my first language. \\
4 & I find idioms difficult to learn because they require knowledge of their cultural background. \\
\hline
\end{tabular}

Table 5. Difficulties arising from the complex nature of idioms

\begin{tabular}{llllllll}
\hline Nature of idioms & Mean & Std. deviation & $\begin{array}{l}\text { Mean } \\
\text { difference }\end{array}$ & $\mathrm{t}$ & $\mathrm{df}$ & $\begin{array}{l}\text { Sig. } \\
\text { (2-tailed) }\end{array}$ & $\begin{array}{l}\text { Level of } \\
\text { agreement }\end{array}$ \\
\hline S.1 & 3.3222 & 1.10999 & 0.27778 & 2.754 & 89 & 0.007 & Average \\
S.2 & 3.6222 & 1.00087 & 0.44318 & 5.898 & 89 & 0.000 & High \\
S.3 & 3.5556 & 1.13287 & 0.50000 & 4.652 & 89 & 0.000 & High \\
S.4 & 3.4778 & 1.15367 & 0.25556 & 3.929 & 89 & 0.000 & High \\
Overall mean & 3.4944 & 0.83882 & 0.36759 & 5.592 & 89 & 0.000 & \\
\hline
\end{tabular}

In general, the results shown in Table 4 demonstrate that the mean of the statements for measuring this dimension has obtained a high degree. The mean score of this dimension is 3.4944 . The highest mean score (3.6222) goes to statement (2), indicating learners avoidance of the use of foreign idioms and their preference for using plain vocabulary. Within the same dimension the lowest mean (3.3222) is scored by statement (1), which relates to linguistic complexities of idioms.

All the items have obtained an arithmetic mean greater than the hypothetical mean $[\mathrm{M}=3]$ approved in the study.

By extrapolating the statistical results shown in Table 5, it is clear that there are statistically significant differences at $(\alpha \leq 0.05)$ between the averages of the answers of the study sample and the hypothetical means approved in the study (hypothetical $\mathrm{M}=3$ ). These appeared in favor of the answers of the study sample, which means there was agreement among the respondents of the sample on the paragraphs that assessed the first dimension and that learners shared a similar belief that the complex nature of idioms is a barrier to their learning.

The second part of the questionnaire (see Table 6 below) considered learners' lack of familiarity with idioms and the neglect of these idioms in learning and teaching contexts.

Table 6. Second dimension (difficulties attributed to lack of familiarity with idioms)

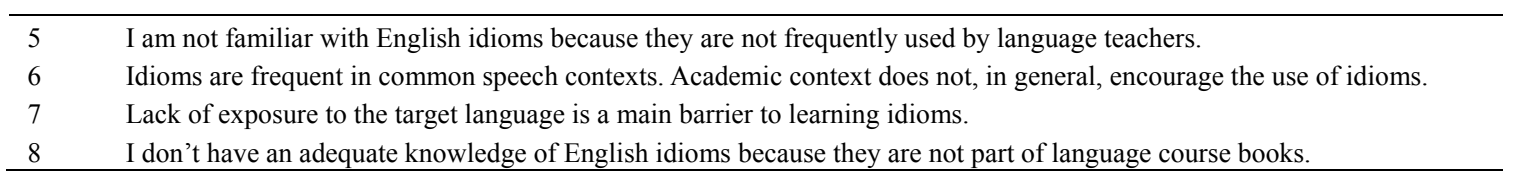

The data presented in Table 7 shows that the subjects' mean scores ranged between 3.5000 and 3.2556. Statements 6 and 7 scored the highest means. This result reveals that subjects seem to share a similar belief about the lack of exposure to idioms in both academic and nonacademic contexts. Results obtained from this $t$ test gives a positive and statistically significant value at $(\alpha \leq 0.05)$, which proves that subjects almost agreed upon all 
these paragraphs, reporting that lack of familiarity is among the barriers to the learning of idioms.

Table 7. Difficulties arising from lack of familiarity with idioms

\begin{tabular}{llllllll}
\hline $\begin{array}{l}\text { Lack of } \\
\text { familiarity }\end{array}$ & Mean & Std. deviation & $\begin{array}{l}\text { Mean } \\
\text { difference }\end{array}$ & $\mathrm{t}$ & $\mathrm{df}$ & $\begin{array}{l}\text { Sig. } \\
\text { (2-tailed) }\end{array}$ & $\begin{array}{l}\text { Level of } \\
\text { agreement }\end{array}$ \\
\hline S.5 & 3.2778 & 1.19011 & 0.27778 & 2.214 & 89 & 0.029 & Average \\
S.6 & 3.4432 & 1.01549 & 0.44318 & 4.094 & 89 & 0.000 & High \\
S.7 & 3.5000 & 1.01947 & 0.50000 & 4.653 & 89 & 0.000 & High \\
S.8 & 3.2556 & 1.20450 & 0.25556 & 2.013 & 89 & 0.047 & Average \\
Overall mean & 3.3676 & 0.79734 & 0.36759 & 4.374 & 89 & 0.000 & Average \\
\hline
\end{tabular}

The last two statements of the student questionnaire were used to estimate EFL majors' awareness of the significance of idioms to language learning. The two statements constitute the third dimension of the questionnaire. The statements and the statistical data for this dimension are displayed in Tables 8 and 9 respectively.

Table 8. Third dimension (significance of idioms)

\begin{tabular}{ll}
\hline 9 & Idioms are important because they can develop language proficiency. \\
10 & I think that the knowledge of idioms would bridge cultural gaps with the target language. \\
\hline
\end{tabular}

Table 9. Learners' view on the importance of idioms

\begin{tabular}{lcclllll}
\hline $\begin{array}{l}\text { Significance of } \\
\text { idioms }\end{array}$ & Mean & Std. Deviation & $\begin{array}{l}\text { Mean } \\
\text { Difference }\end{array}$ & T & df & $\begin{array}{l}\text { Sig. } \\
\text { (2-tailed) }\end{array}$ & $\begin{array}{l}\text { Level of } \\
\text { agreement }\end{array}$ \\
\hline q.9 & 3.9222 & 0.96253 & 0.92222 & 9.090 & 89 & 0.000 & High \\
q.10 & 3.9667 & 0.98813 & 0.96667 & 9.281 & 89 & 0.000 & High \\
Overall mean & 3.9444 & 0.86908 & 0.94444 & 10.309 & 89 & 0.000 & High \\
\hline
\end{tabular}

The two items scored a high degree, and the $t$ test gave a positive and statistically significant value at $(\alpha \leq 0.05)$, which indicate that respondents are aware of the significance of idioms to language learning.

\subsection{Data Analysis of the Teacher Questionnaire}

In this section the writer discusses the statistical results obtained from the ELT teachers' questionnaire. The data were gained from the responses of a total sample of $20 \mathrm{EFT}$ teachers at the tertiary level. The questionnaire was intended to assess theses teachers' views on the pedagogical impact of idiomaticity.

The items of the questionnaire cover three domains:

- The first domain (measured by statements 1-4) questions whether the lexical, syntactic, and semantic abnormalities of idioms have an impact on their learnability.

- The second domain (measured by statements 5-8) rates teachers' interest in teaching idioms.

- The third domain (measured by statements 9-11) assesses the relevance of idioms to language curricula and syllabi.

Due to the small and controlled sample of respondents and to the expectations of reliable and rational replies from the teachers', the researcher used only some basic statistical measures to analyze the data obtained. 
Table 10. Descriptive statistics of the teacher questionnaire

\begin{tabular}{llllllllllll}
\hline & $\mathrm{q} 1$ & $\mathrm{q} 2$ & $\mathrm{q} 3$ & $\mathrm{q} 4$ & $\mathrm{q} 5$ & $\mathrm{q} 6$ & $\mathrm{q} 7$ & $\mathrm{q} 8$ & $\mathrm{q} 9$ & $\mathrm{q} 10$ & $\mathrm{q} 11$ \\
\hline $\mathrm{N} \mathrm{Valid}$ & 20 & 20 & 20 & 20 & 20 & 20 & 20 & 20 & 20 & 20 & 20 \\
$\quad$ Missing & 0 & 0 & 0 & 0 & 0 & 0 & 0 & 0 & 0 & 0 & 0 \\
Mean & 4.0000 & 4.2500 & 4.0500 & 3.4000 & 3.6500 & 3.5500 & 3.8500 & 3.5000 & 3.6000 & 3.1500 & 4.3000 \\
Median & 4.0000 & 4.5000 & 4.0000 & 4.0000 & 4.0000 & 3.0000 & 4.0000 & 4.0000 & 4.0000 & 3.0000 & 4.5000 \\
Std. & 1.02598 & 0.91047 & 1.14593 & 1.46539 & 1.13671 & 0.82558 & 0.81273 & 1.05131 & 1.42902 & 1.13671 & 0.86450 \\
$\begin{array}{l}\text { Deviation } \\
\text { Mean }\end{array}$ & 4.00000 & 4.00000 & 4.00000 & 4.00000 & 4.00000 & 4.00000 & 4.00000 & 4.00000 & 4.00000 & 4.00000 & 4.00000 \\
Difference & & & & & & & & & & & \\
Sig. (2-tailed) & .000 & .000 & .000 & .000 & .000 & .000 & .000 & .000 & .000 & .000 & .000 \\
\hline
\end{tabular}

It can generally be seen that the difference between the means of scores is statistically significant (the significance value is $a \leq 0.05$ ).

Table 10 shows the statistical description of the questionnaire items. It shows that the mean scores range between 3.15000 and 4.5000 . The highest mean goes to the statement "Idioms constitute a vast category that covers a wide range of expressions and could hardly be recognized as a homogenous class, so they cannot be incorporated in vocabulary syllabus," and the lowest to "Learners' poor idiomatic competence is due to the lack of attention towards idioms at the school stage." This result reveals a contrast in the teachers' perspectives regarding idioms. They do not admit the inclusion of idioms in language syllabi, while at the same time they attribute the same problem to the exclusion of idioms from language syllabi at the school stage.

Results generally indicate a moderate mean for most of the statements, except for the first three statements of the first domain, which assessed teachers' perspective of the learnability of idioms that scored the highest means (from 40000 to 42500). The three statements tackled the factors that relate to cultural and lexical barriers as well as the lack of exposure to the idioms of the target language. Interestingly, both teachers and learners shared similar views that both linguistic and cultural features of idioms are among their learning barriers.

As for the second domain (measured by statements 5-8), which rated teachers' interest in the teaching of idioms, average means (between 3.5000 and 3.8500) were scored. The data do not reflect a general consensus on any items assessed. Almost half of respondents were unable to determine whether to frequently use idiomatic language or not (statement 6). Meanwhile, the data evidence that although students were almost unanimously agreed that lack of familiarity is among the barriers to the learning of idioms, teachers (statement 8) did not come to a similar conclusion. Only $40 \%$ of the respondents admitted lack of familiarity with linguistic research relevant to the question of idiomaticity. Though the phrase "lack of familiarity" is understood with a different meaning with respect to teachers, it has its impact on teachers' enthusiasm for introducing idioms to learners.

It may be noted from Table 10 that the median for most statements, except for 6 and 10 , is 4 , which is interpreted according to the Likert scale as agree. This suggests that participants widely agreed on the questionnaire statements aimed at confirming the research hypotheses. However, the frequencies of the responses to the sixth statement "Classroom discourse is typically featured by formal and neutral vocabulary. I do not frequently use idiomatic language" (See Table 11) clearly reveal uncertainty among teachers as seen by the high percentage of the option "neutral."

Table 11. Frequencies of statement 6

\begin{tabular}{llll}
\hline & & Frequencies & Percentage \\
\hline Valid & Disagree & 1 & 5.0 \\
& Neutral & 10 & 50.0 \\
& Agree & 6 & 30.0 \\
& Strongly agree & 3 & 15.0 \\
\hline
\end{tabular}

\section{Conclusion}

The purpose of the current study was to investigate the impact of idiomaticity on language learning. Findings generally indicate that idioms are a source of difficulty in many ways. The notion of idiomaticity, which mainly draws on complicated features of idioms, is responsible for setting up idioms as a learning barrier. The findings of this study reveal that learners are sensitive toward idioms for various reasons. The first is the vague nature of idioms. Because learning a language is, in general, based on logical and systematic inputs, learners find a 
contrast to the usual order when encountering idioms. The data obtained from this study show a negative attitude toward the linguistic complexities and irregularities of idioms. The results also point to a lack of familiarity with and exposure to idioms of the target language. Overall, learners exhibit positive attitudes toward learning English idioms. These findings are in line with those obtained from the studies of Ababneh (2016), Al-Houtil and Aldaihani1 (2018), and Tadayyon and Ketabi (2014). However, when learners assume a negative attitude toward idioms, teachers cannot be omitted from such accounts. This is because teachers' beliefs and opinions absolutely have an influence on students' learning. As for the current study, the findings generally prove teachers' poor interest in teaching idioms, which even extends to a reluctance to be concerned about linguistic research relevant to the question of idiomaticity.

Although the study reveals that both teachers and learners are interested in the subject matter of idioms, there is a general dissatisfaction with their status in learning and teaching contexts.

The current study involved two groups (EFL college students and EFL college teachers) in a contrast aimed at assessing their views on the question of idiomaticity. The two groups constituted two independent entities, which are commonly assessed independently on the same research issue. The researcher claims that it is possible to obtain reliable and significant findings when conducting research applying similar methods.

\section{Acknowledgements}

This research project was supported by the Deanship of Scientific Research at Prince Sattam bin Abdulaziz University, Kingdom of Saudi Arabia, under the research project No. 2019/2/9439.

\section{References}

Ababneh, S. (2016). Attitudes of Jordanian EFL students towards learning English idioms. International Journal of English Language Education, 4(1), 172-181. https://doi.org/10.5296/ijele.v4i1.9171

Al-Houti, S. K., \& Aldaihani, S. M. (2018). Letting the cat out of the bag: EFL college students' attitudes towards learning English idioms. International Journal of Higher Education, 7(1), 140-150. https://doi.org/10.5430/ijhe.v7n1p140

Fernando, C., \& Flavell, R. (1981). On idiom: critical views and perspectives. Exeter: Univ.

Gabillon, Z. (2012). Revisiting foreign language teacher beliefs (pp. 190-203).

Kaszubski, P. (2001). Tracing idiomaticity in learner language: The case of BE. In P. Rayson, A. Wilson, T. McEnery, A. Hardie \& S. Khoja (Eds.), Proceedings of the Corpus Linguistics 2001 Conference (pp. 312 322). UCREL Tech, Lancaster.

Moon, R. (2003). Fixed expressions and idioms in English: A corpus-based approach. Oxford: Clarendon Press.

Najarzadegan, S., \& Ketabi, S. (2015). Teachers' Beliefs about Teaching Idiomatic Expressions: The Case of Iranian EFL Learners. Journal of Applied Linguistics and Language Research, 2(3), 120-132.

Noor, H., \& Fallatah, M. (2010). An investigation of some difficulties in idioms encountered by Saudi learners of English. International Journal of Arabic-English Studies (IJAES), 11, 147-173.

Nunberg, G., Sag, I. A., \& Wasow, T. (1994). Idioms. Language, 70(3), 491-538. https://doi.org/10.1353/lan.1994.0007

Pucelj, M. (2018, October 24). Attitudes towards idioms and idiom learning strategies. FFOS, Sveučilište Josipa Jurja Strossmayera u Osijeku. Filozofski Fakultet. Odsjek Za Engleski Jezik i Književnost. Retrieved from https://repozitorij.ffos.hr/islandora/object/ffos: 4212

Ramonda, K. (2016). A bone of contention: Teacher beliefs on the pedagogical value of English idioms for second language learners. The Reading Matrix, 16, 131-143.

Rifai, N. (2010) Attitude, Motivation, and Difficulties Involved in Learning the English Language and Factors that Affect Motivation in Learning it. Procedia Social and Behavioral Sciences, 2, 5216-5227. https://doi.org/10.1016/j.sbspro.2010.03.849

Rizq, W. (2005). Teaching English Idioms to L2 Learners: ESL Teachers' Perspective. Culminating Projects in English, 19. Retrieved from https://repository.stcloudstate.edu/engl_etds/19

Tadayyon, M., \& Ketabi, S. (2014). Iranian EFL learners' attitude towards idioms in English. Theory and Practice in Language Studies, 4(3), 608-612. https://doi.org/10.4304/tpls.4.3.608-612

Warren, B. (2005). A Model of Idiomaticity. Nordic Journal of English Studies, 4(1), 35-54. https://doi.org/10.35360/njes.172 


\section{Copyrights}

Copyright for this article is retained by the author, with first publication rights granted to the journal.

This is an open-access article distributed under the terms and conditions of the Creative Commons Attribution license (http://creativecommons.org/licenses/by/4.0/). 